\title{
PENGEMBANGAN VIDEO DOKUMENTER MENGENAI \\ ROLE MODEL YANG MEMILIKI EMPLOYABILITY SKILLS UNTUK PESERTA DIDIK KELAS XII IPS SMA NEGERI 14 JAKARTA
}

\author{
Wening Cahyawulan ${ }^{1}$ \\ Andita Ratih ${ }^{2}$
}

\begin{abstract}
Abstrak
Penelitian ini bertujuan untuk mengembangkan video pembelajaran berupa video dokumenter mengenai role model yang memiliki employability skills. Penelitian ini ditujukan kepada peserta didik kelas XII IPS SMA Negeri 14 Jakarta. Jumlah populasi pada penelitian ini sebanyak 72 orang peserta didik. Teknik sampling yang digunakan adalah sampling jenuh dengan jumlah sampel 72 orang peserta didik. Metode penelitian yang digunakan peneliti adalah metode research and development (R\&D) dengan menggunakan model ADDIE (Analyze, Design, Development, Implementation, dan Evaluation). Adapun tahapan pengembangan yang dilakukan peneliti yaitu tahap analisis, desain, dan pengembangan. Video dokumenter ini memuat informasi mengenai definisi, ciri-ciri individu yang memiliki keterampilan tersebut, dan urgensi keterampilan tersebut dalam dunia karier pada keterampilan manajemen diri, komunikasi, kepemimpinan, kecerdasan emosional, kerjasama, keberanian berusaha, kesadaran pada karier, keterampilan menyelesaikan masalah, keterampilan mengelola teknologi dan informasi, dan keterampilan matematik. Penilaian produk dilakukan oleh validator yang terdiri dari ahli media, ahli materi, dan peserta didik. Berdasarkan penilaian media yang telah dilakukan, diperoleh hasil uji validitas media $81,25 \%$ dan termasuk kategori layak. Uji validitas materi memperoleh hasil 77,56\% dan termasuk kategori layak. Serta penilaian peserta didik memperoleh hasil 71,25\% dan termasuk kategori layak.

Kata Kunci: Pengembangan, research and development, Model ADDIE, video, karier, keterampilan kerja.
\end{abstract}

\begin{abstract}
The purpose of this study to develop documentary video about role models that have employability skills for students of class XII IPS at 14 State High School Jakarta. The population in this study are 72 students. The sampling technique is saturated sampling with a sample of 72 students. The research method is research and development $(R \& D)$ method using the ADDIE model (Analyze, Design, Development, Implementation, and Evaluation). The stages are analysis, design, and development. The documentary video contains information about definitions, characteristics of individuals who have these skills, and urgency of these skills in the career world in self-management, communication, leadership, emotional intelligence, teamwork, courage to try, career awareness, problem solving skills,
\end{abstract}

\footnotetext{
${ }^{1}$ Universitas Negeri Jakarta, wening@unj.ac.id

${ }^{2}$ Universitas Negeri Jakarta, andita.ratihh@gmail.com
} 
manage technology and information skills, and mathematical skills. Product assessment is carried out by a validator consisting of media experts, material experts, and students. Based on media assessment, the results of the media validity test are feasible $(81,25 \%)$. Based on material assessment, the results of the material validity test are feasible (77,56\%). Based on student assessment, the results are feasible $(71,25 \%)$.

Keywords: Development, research and development, ADDIE model, video, career, employability skills.

\section{PENDAHULUAN}

Dalam teori perkembangan karier remaja, Ginzberg menjelaskan bahwa peserta didik SMA pada usia sekitar 17 hingga 18 tahun berada pada masa transisi. Pada masa tersebut remaja mulai menyadari untuk menentukan sendiri masa depannya dan harus mengambil tindakan untuk melakukannya, meski belum mampu mengambil keputusan dengan segera. Ide mengenai gaji yang pantas, kebutuhan pendidikan, dan kondisi kerja menjadi hal yang lebih penting pada tahap ini daripada dua tahun yang lalu (Sharf, 1992).

Pada Standar Kompetensi Kemandirian Peserta Didik (SKKPD) SMA/MA/SMK terdapat salah satu aspek perkembangan yang berkaitan dengan bidang karier di mana remaja ditargetkan untuk mempelajari kemampuan diri, peluang dan ragam pekerjaan, pendidikan dan aktifitas yang terfokus pada pengembangan alternatif karier yang lebih terarah. Maka itu, remaja perlu memiliki pengetahuan mengenai employability skills untuk menunjang tercapainya aspek perkembangan tersebut.

Dalam Standar Nasional America School Counselor Association (ASCA) untuk peserta didik dijelaskan di bagian pengembangan karier bahwa peserta didik perlu memperoleh employability skills seperti kerjasama dalam tim, keterampilan menyelesaikan masalah, dan keterampilan mengorganisasi dalam rangka membangun kesiapan kerja. Hal tersebut mempertegas bahwa peserta didik SMA perlu memiliki pengetahuan mengenai employability skills.

Hasil penelitian yang dilakukan oleh Suhartini (2015) menjelaskan bahwa employability skills memiliki pengaruh yang positif dan signifikan terhadap kinerja karyawan, serta membuat karyawan mempertimbangkan realita ketatnya kompetisi dalam bidang ekonomi dan perdagangan, maka sebuah usaha harus memikirkan strategi pengelolaan usaha dengan sumber daya manusia yang mempunyai pengetahuan, keterampilan dan kemampuan kerja yang baik serta manajerial yang profesional dalam menjalankan usahanya. Penelitian tersebut memberikan gambaran tentang kebutuhan remaja pada employability skills sebagai bekal di masa depan.

Employability skills adalah keterampilan untuk mengidentifikasi masalah dan prioritas yang terkait dengan tindakan individu dan institusi yang terlibat dalam akses terhadap karier (Gazier, 2001). Employability skills disebutkan juga sebagai keterampilan yang dibutuhkan untuk masuk, bertahan, dan berkembang dalam dunia kerja secara individual maupun kelompok (The Conference Board of Canada, 2000). Dalam bukunya yang berjudul Brilliant Employability skills, Trought (2017) menyatakan keterampilan kerja merupakan cakupan keterampilan yang cukup luas dan dibagi menjadi beberapa keterampilan, yaitu manajemen diri, komunikasi, kesadaran pada karier, kerjasama, penyelesaian masalah, keterampilan mengelola teknologi dan informasi, keterampilan matematik, keberanian berusaha, kepemimpinan, dan kecerdasan emosional.

Hasil preliminary study tentang tingkat pengetahuan peserta didik mengenai employability skills didapati bahwa sebagian 
besar peserta didik sudah memahami beberapa keterampilan dalam employability skills. Namun, hasil dari preliminary study juga menunjukan bahwa peserta didik kelas XII IPS SMA Negeri 14 Jakarta belum memiliki pengetahuan secara keseluruhan.

Peraturan Menteri Pendidikan dan Kebudayaan Republik Indonesia Nomor 111 Tahun 2014 tentang Bimbingan dan Konseling Pada Pendidikan Dasar dan Pendidikan Menengah pasal 9 ayat 1 yang berbunyi: "Layanan Bimbingan dan Konseling pada satuan pendidikan dilakukan oleh Konselor atau Guru Bimbingan dan Konseling." Dan dalam ayat 2 berbunyi: "Tanggung jawab pelaksanaan layanan Bimbingan dan Konseling pada satuan pendidikan dilakukan oleh Konselor atau Guru Bimbingan dan Konseling." Dari dua ayat tersebut jelas bahwa guru BK harus memberikan layanan bimbingan dan konseling, salah satunya adalah kegiatan bimbingan klasikal.

Bimbingan dan konseling memiliki tugas untuk membantu tercapainya tugas perkembangan peserta didik, salah satunya melalui kegiatan bimbingan klasikal. Secara rinci tujuannya dapat dirumuskan sebagai upaya untuk membantu konseli agar (1) memiliki kesadaran (pemahaman) tentang diri dan lingkungannya (pendidikan, pekerjaan, sosial budaya dan agama); (2) mampu mengembangkan keterampilan untuk mengidentifikasi tanggung jawab atau seperangkat tingkah laku yang layak bagi penyesuaian diri dengan lingkungannya; (3) mampu memenuhi kebutuhan dirinya dan mampu mengatasi masalahnya sendiri; dan (4) mampu mengembangkan dirinya dalam rangka mencapai tujuan hidupnya. Untuk mencapai tujuan tersebut, fokus pengembangan kegiatan yang dilakukan diarahkan pada perkembangan aspek-aspek pribadi, sosial, belajar dan karir. Semua ini berkaitan erat dengan upaya membantu peserta didik dalam mencapai tugas-tugas perkembangan dan kemandirian dalam kehidupannya.

Media merupakan salah satu komponen penting dalam kegiatan bimbingan klasikal.
Media menunjang guru BK mencapai tujuan dari pelaksanaan kegiatan bimbingan klasikal tersebut. Media pun mampu membuat metode bimbingan yang digunakan menjadi menarik bagi peserta didik.

Di SMA Negeri 14 Jakarta setiap minggunya kegiatan bimbingan klasikal berlangsung selama satu jam pelajaran di tiap kelas. Berdasarkan hasil preliminary study diketahui guru BK menggunakan papan tulis, kertas, PowerPoint, poster, video motivasi, dan buku untuk kegiatan bimbingan klasikal. Selama ini guru BK menggunakan kuis, permainan, diskusi, dan ceramah sebagai metode bimbingan di kelas. Hal tersebut menunjukan bahwa guru BK tidak pernah menggunakan video dokumenter dalam kegiatan bimbingan klasikal.

Puspitasari (2014) dalam penelitiannya menyatakan bahwa penggunaan video dokumenter sebagai media yang dilaksanakan di sekolah dapat meningkatkan prestasi belajar peserta didik. Secara spesifik berdasarkan hasil penelitian. Monica dan Susanti (2016) menyimpulkan bahwa pelaksanaan kegiatan bimbingan klasikal efektif menggunakan media audiovisual (video) untuk mengembangkan interaksi sosial peserta didik. Hal ini didukung juga melalui wawancara dengan guru-guru BK di SMA Negeri 14 Jakarta yang menyatakan bahwa peserta didik memiliki ketarikan pada informasi karier dan video dokumenter sebagai media pembelajaran yang digunakan dalam kegiatan bimbingan klasikal.

Hasil preliminary study mengenai role model dibuat berdasarkan beberapa bagian, yaitu jenis kelamin, kelompok usia, dan bidang profesi atau pekerjaan. Peserta didik cenderung memilih role model dengan jenis kelamin laki-laki di kelompok usia 24-35 tahun yang memiliki profesi atau pekerjaan di bidang pendidikan.

Erikson (1968) menyatakan bahwa masa remaja merupakan masa krisis identitas. Tugas dasarnya adalah kesetiaan atau 
kebenaran dan konsistensi terhadap inti diri atau kepercayaan diri terhadap ideologi. Remaja tidak hanya belajar "siapa mereka", tetapi pada saat bersamaan remaja belajar untuk menentukan dan menemukan diri sendiri. Mereka meniru role model dan mencoba identitas seperti mencoba pakaian baru (E. Erikson, 2004). Pada proses pencarian dan pembentukan jati diri remaja membutuhkan role model yang tepat untuk ditiru dalam hidupnya.

Oleh karena itu, melalui penelitian ini peneliti akan mengembangkan media video dokumenter mengenai role model yang memiliki employability skills untuk remaja, khususnya peserta didik kelas XII IPS SMA Negeri 14 Jakarta. Video dokumenter akan berisi konten seorang pekerja yang memiliki employability skills. Video pun akan dibuat dengan mengacu pada data dan disesuaikan dengan perencanaan dan ketersediaan di lapangan agar mencapai tujuan penelitian.

\section{Video Dokumenter}

Video dokumenter adalah produk audiovisual yang berisi pengalaman atau cerita tertentu dan bersifat nonfiktif (Desrianti, Rahardja, \& Mulyani, 2012) dengan durasi sekitar 10 menit (Bawantara, 2008) atau di bawah 60 menit (Rikarno, 2015). Video dokumenter berhubungan langsung dengan orang, tokoh, peristiwa, dan lokasi yang nyata. Video dokumenter tidak menciptakan suatu peristiwa atau kejadian, namun peristiwa tersebut sungguhsungguh terjadi dan memiliki struktur yang umumnya didasarkan oleh tema atau argumen (Ramli et al., 2017). Video dokumenter menggunakan potonganpotongan film, materi tertulis, pidato, ceramah, dan cara persuasi lainnya (Aitken, 2013). Pembuatan video dokumenter dimulai dari praproduksi, produksi, hingga pascaproduksi (Fachruddin, 2015). Untuk editing video dokumenter, terlebih dahulu dilakukan editing script sebelum assembly editing (proses kerja editor untuk menyusun kembali materi editing berdasarkan naskah yang diberikan secara berurutan baik itu shot yang baik ataupun tidak baik), karena pada video dokumenter biasanya ada shot yang dibuat di luar rencana dan editing bisa juga dilakukan dengan menggunakan pola cut away cutting (memotong ke klip yang benarbenar berbeda dan kemudian kembali ke tindakan awal) (Santoso, 2013).

\section{Gaya Video Dokumenter}

Video dokumenter memiliki karakter tersendiri agar penonton menikmati video tersebut. Sensasi yang ingin dibangun dan penonton rasakan ditentukan dari gaya video dokumenter. Berikut ini adalah lima gaya atau cara pemaparan video dokumenter (Fachruddin, 2017):

1. Dokumenter eksposisi: memiliki ciri khas menggunakan narator sebagai punutur tunggal.

2. Dokumenter observasi: memiliki konsentrasi pada dialog antarsubjek. Produser (director) posisinya sebagai observer (pengamat) dan alur cerita cenderung datar.

3. Dokumenter interaktif: produser berperan aktif (partisipan). Adegan komunikasi antara sutradara dengan subjek video terlihat jelas. Jika ada adegan wawancara tidak hanya menampilkan adegan wawancara, tetapi juga bagaimana wawancara dilakukan.

4. Dokumenter refleksi: menggambarkan kamera bagaikan mata film yang merekam realitas. Fokus utama pengemasannya pada penuturan proses pembuatan video.

5. Dokumenter performatif: memiliki fokus utama pada kemasan. Kemasan harus semenarik mungkin, alur penuturan (plot) lebih diperhatikan. Video dokumenter dengan gaya ini digolongkan sebagai semidokumenter.

Gaya atau cara pemaparan video dokumenter menunjukan seberapa jauh sumber daya atau pihak yang terlibat dalam video dokumenter muncul di dalam video. Gaya video dokumenter dipengaruhi oleh tujuan dari video dokumenter tersebut. Hal 
tersebut dapat dilakukan dengan melakukan analisa pada sasaran video dokumenter.

\section{Jenis Video Dokumenter}

Pada bidang seni-budaya seperti musik, film, dan sastra terdapat kategorisasi atau istilah yang biasa disebut dengan genre. Video dokumenter pun memiliki 11 jenis (Fachruddin, 2017), yaitu: (1) dokumenter laporan perjalanan, (2) dokumenter sejarah, (3) dokumenter biografi, (4) dokumenter kontradiksi, (5) dokumenter ilmu pengetahuan, (6) dokumenter nostalgia, (7) dokumenter rekonstruksi, (8) dokumenter seni/eksperiman, (9) dokumenter investigasi, (10) dokumenter drama, dan (11) dokumenter buku harian. Sedangkan jenis video documenter yang akan digunakan oleh peneliti adalah dokumenter biografi dan dokumenter ilmu pengetahuan. Berikut ini adalah penjelasan mengenai jenis video tersebut:

1. Dokumenter biografi

Dokumenter biografi memiliki penekanan pada sosok seseorang. Mereka yang diangkat menjadi tema utama biasanya seseorang yang dikenal luas atau seseorang yang biasa tetapi memiliki kehebatan, keunikan ataupun aspek lain yang menarik.

2. Dokumenter ilmu pengetahuan

Dokumenter ilmu pengetahuan berisi penyampaian informasi mengenai suatu teori, sistem, berdasarkan disiplin ilmu tertentu. Kemasannya bisa berupa video edukasi jika ditujukan kepada publik khusus atau video instruksional jika ditujukan kepada publik umum.

\section{Employability skills (Keterampilan Kerja)}

Keterampilan kerja (employability skills) adalah keterampilan untuk mengidentifikasi masalah dan prioritas yang terkait dengan tindakan individu dan institusi yang terlibat dalam akses terhadap karier (Gazier, 2001). Keterampilan kerja disebutkan juga sebagai keterampilan yang dibutuhkan untuk masuk, bertahan, dan berkembang dalam dunia kerja secara individual maupun kelompok (The Conference Board of Canada, 2000).

Employability skills merupakan soft skills yang dibutuhkan individu dalam memasuki dunia karier. Employability skills merupakan soft skills yang perlu dimiliki oleh peserta didik SMK karena pada dasarnya peserta didik dipersiapkan untuk bekerja setelah lulus sekolah. Namun employability skills tidak dibatasi hanya untuk jenjang SMK. Berdasarkan kurikulum pendidikan jenjang SMA, peserta didik SMA pun memiliki kebutuhan untuk memiliki pengetahuan mengenai employability skills. Hal tersebut perlu dipersiapkan sejak dini sebagai bekal memasuki dunia karier (Suneela, 2014).

Trought (2017) menyatakan keterampilan kerja merupakan cakupan keterampilan yang cukup luas dan dibagi menjadi beberapa keterampilan sebagai berikut:

\section{Keterampilan Manajemen Diri}

1. Definisi

Keterampilan manajemen diri adalah keterampilan untuk menerima tanggung jawab, fleksibilitas, ketahanan, inisiatif, ketegasan yang tepat, manajemen waktu, dan kesiapan untuk memperbaiki kinerja sendiri berdasarkan umpan balik atau pembelajaran reflektif (Central Bureau of Investigation, 2011).

2. Ciri-ciri individu yang memiliki keterampilan manajemen diri (Trought, 2012)

a. Mampu mengatur waktu secara efektif.

b. Memiliki inisiatif.

c. Mampu belajar dari pengalaman.

d. Menggunakan umpan balik dan refleksi untuk melihat bagaimana individu bisa melakukan tugas dengan lebih baik.

e. Mampu melihat diri punya kesempatan untuk perbaikan.

f. Mampu melakukan persiapan, perencanaan dan organisasi sangat 
untuk pengelolaan waktu yang efektif.

g. Memiliki gaya hidup sehat.

h. Mampu mengetahui dan memahami perasaan dan pikiran diri sendiri.

i. Mampu memanfaatkan kemampuan diri.

3. Urgensi keterampilan manajemen diri dalam dunia karier

a. Membantu individu memiliki kesiapan untuk memperbaiki kinerja sendiri berdasarkan umpan balik atau pembelajaran reflektif (Gracinia \& Mulyani, 2013).

b. Membantu individu mengendalikan keberadaan diri secara keseluruhan (fisik, emosi, mental atau pikiran, jiwa maupun rohnya) dan realita kehidupannya (Prijosaksono, 2001).

\section{Keterampilan Kerjasama}

1. Definisi

Keterampilan kerjasama adalah kemampuan individu untuk menghormati orang lain, bekerja dengan orang lain, bernegosiasi atau meyakinkan, berkontribusi dalam diskusi, proyek, atau tugas, dan memiliki kesadaran akan saling ketergantungan dengan orang lain (Central Bureau of Investigation, 2011).

2. Ciri-ciri individu yang memiliki keterampilan kerjasama (Trought, 2017)

a. Mampu menghormati orang lain.

b. Mampu bekerja dengan orang lain.

c. Mampu bernegosiasi.

d. Mampu berkontribusi.

e. Memiliki kesadaran akan saling ketergantungan dengan orang lain.

f. Berorientasi pada tercapainya tujuan yang baik.

g. Memperhatikan kepentingan bersama.

h. Memiliki prinsip untuk saling menguntungkan.

3. Urgensi keterampilan kerjasama dalam dunia karier

a. Kerjasama dapat memberi nilai tambah pada hasil sebuah tugas, proyek, atau tim (The Conference Board of Canada, 2000). b. Kerjasama yang baik memiliki tujuan yang disepakati bersama dan saling menguntungkan bagi pihakpihak yang berada dalam tim (Baron \& Branscombe, 2014).

\section{Kesadaran pada Karier}

1. Definisi

Kesadaran pada karier merupakan kemampuan individu untuk mengenali karier sehingga individu mampu memahami target, tujuan, dan tantangan dalam karier (Syafitri \& Heriyanto, 2013)

2. Ciri-ciri individu yang memiliki kesadaran pada karier (Trought, 2017)

a. Mampu mengerti dan memahami diri sendiri.

b. Mampu menjadi diri sendiri.

c. Mengetahui dan memahami potensi yang dimiliki.

d. Mengetahui dan memahami keputusan yang diambil.

e. Mengetahui dan memahami perasaan yang dirasakan (afeksi).

f. Mengetahui dan memahami nilainilai yang dimiliki.

g. Mampu memahami target, tujuan, dan tantangan yang harus dihadapi dalam bekerja.

h. Memiliki pemahaman dasar tentang pendorong kesuksesan utama pekerjaan.

i. Memiliki inovasi dan mampu mengambil risiko yang dapat diperhitungkan.

j. Memiliki kesadaran pada prosedur kesehatan dan keselamatan pribadi dan kelompok.

k. Mampu bertindak sesuai dengan kesepakatan tim.

3. Urgensi kesadaran pada karier dalam dunia karier (The Conference Board of Canada, 2000)

a. Memberi nilai tambah bagi organisasi tempat bekerja.

b. Memberikan kepuasan target dan membangun loyalitas target.

c. Mendorong usaha maksimal dalam mencapai tujuan karier. 


\section{Keterampilan Menyelesaikan Masalah}

1. Definisi

\begin{tabular}{ccr}
\multicolumn{2}{c}{ Keterampilan } & menyelesaikan \\
masalah & merupakan & kemampuan \\
individu & dalam & mengenali,
\end{tabular}
mengidentifikasi, mendefinisikan, menganalisa fakta dan situasi dari masalah yang dihadapi, serta menerapkan pemikiran kreatif untuk mengembangkan solusi yang tepat melalui penafsiran strategi yang memungkinkan (National Union of Students, 2011).

2. Ciri-ciri individu yang memiliki keterampilan menyelesaikan masalah (Trought, 2017)
a. Mampu menganalisa fakta dan situasi.
b. Memiliki pemikiran kreatif.
c. Mampu mengidentifikasi dan mengenal masalah.
d. Mampu mendefinisikan dan menggambarkan masalah.
e. Mampu menafsirkan strategi yang memungkinkan.
f. Mampu bertindak sesuai dengan strategi.
g. Mampu melakukan evaluasi dan perencanaan tindak lanjut.
h. Memiliki inisiatif.

3. Urgensi keterampilan menyelesaikan masalah dalam dunia karier (Trought, 2017)

a. Mengembangkan solusi terhadap tantangan masa depan.

b. Dunia kerja memiliki kebutuhan pada individu yang dapat mengembangkan solusi inovatif.

c. Membuat individu kompetitif dalam bekerja.

\section{Keterampilan Komunikasi}

1. Definisi

Keterampilan komunikasi adalah proses interaksi manusia melalui penerimaan dan pemberian pesan yang terdiri dari pemberi pesan dan penerima pesan dengan tujuan untuk mempengaruhi cara berpikir dan pola perilaku sehingga terjadinya perubahan pada individu maupun lingkungan dalam bentuk verbal dan nonverbal (Wiryanto, 2004).

2. Ciri-ciri individu yang memiliki keterampilan komunikasi (Trought, 2017)

a. Memahami konteks pesan yang disampaikan.

b. Mampu memilih media yang tepat untuk pengiriman.

c. Mampu memilih kata-kata dalam komunikasi dengan seksama.

d. Mampu mengantisipasi situasi yang memungkinkan penerima pesan salah tafsir terhadap pesan yang diterima.

e. Memahami betul penggunaan bahasa internet.

f. Mampu berkomunikasi dengan intonasi, artikulasi, dan ekspresi visual yang baik.

g. Mampu berkomunikasi secara efektif.

3. Urgensi keterampialan komunikasi dalam dunia karier (The Conference Board of Canada, 2000)

a. Negosiasi

b. Mediasi

c. Komunikasi yang baik dengan rekan kerja

d. Mendorong tercapainya tujuan pekerjaan

e. Mendorong kerjasama yang baik dalam tim

\section{Keterampilan Mengelola Teknologi dan Informasi}

1. Definisi

Keterampilan mengelola teknologi dan informasi merupakan kemampuan individu dalam memahami, mengoperasikan, dan mengakses teknologi dan informasi yang hendak dikelola, serta menganalisa dan menerapkan pengetahuan dan keterampilan dari berbagai disiplin ilmu (misalnya seni, bahasa, sains, teknologi, matematika, ilmu sosial, dan humaniora) (Trought, 2017). 
2. Ciri-ciri individu yang memiliki keterampilan mengelola teknologi dan informasi (Trought, 2017)

a. Memiliki berbagai keterampilan dasar teknologi dan informasi.

b. Menerapkan teknologi dan informasi sebagai alat manajemen.

c. Menggunakan teknologi dan informasi untuk mengatur data.

d. Bersedia untuk belajar keterampilan mengelola teknologi dan informasi baru.

e. Memiliki pengetahuan tentang kesehatan dan keselamatan kerja untuk menggunakan teknologi dengan cara yang aman dan sehat.

f. Mampu mencari, mengumpulkan, dan mengatur informasi menggunakan teknologi dan sistem informasi yang sesuai.

g. Mampu mengakses, menganalisis, dan menerapkan pengetahuan dan keterampilan dari berbagai disiplin ilmu (misalnya seni, bahasa, sains, teknologi, matematika, ilmu sosial, dan humaniora).

3. Urgensi keterampilan mengelola teknologi dan informasi dalam dunia karier (The Conference Board of Canada, 2000)

a. Teknologi mampu mengubah, mengganggu, dan membentuk kembali semua aspek kehidupan.

b. Kemajuan dramatis dalam teknologi menyebabkan dunia mengembangkan tujuan mereka di masa depan.

c. Penerapan teknologi melibatkan individu sebagai pekerja agar memiliki kemampuan untuk mendemonstrasikan keterampilan dasar teknologi seperti kemampuan pengolahan kata, spreadsheet, pengelolaan file dan email.

\section{Keterampilan Matematik}

1. Definisi

Keterampilan matematik merupakan kemampuan individu dalam mengklasifikasi data, menentukan hal- hal yang dapat diukur dan dihitung dari proyek atau tugas yang dikerjakan, lalu menganalisa, menafsirkannya dan mempresentasikan data tersebut dalam format visual (Trought, 2017).

2. Ciri-ciri individu yang memiliki keterampilan matematik (Trought, 2017)

a. Mampu memahami arti berhitung bidang karier yang digeluti.

b. Memiliki pemahaman tentang tugas aritmatika seperti penambahan, pengurangan, perkalian dan pembagian.

c. Mampu menganalisa data kuantitatif dan kualitatif.

d. Mampu menafsirkan dan mempresentasikan data dalam format visual.

e. Mampu memutuskan apa yang perlu diukur atau dihitung.

f. Mampu mengamati dan mencatat data dengan menggunakan metode, alat, dan teknologi yang tepat.

g. Mampu membuat perkiraan dan verifikasi perhitungan.

3. Urgensi keterampilan matematik dalam dunia karier (The Conference Board of Canada, 2000)

a. Mendukung keputusan yang dibuat dalam dunia karier.

b. Mendorong tercapainya tujuan pekerjaan.

\section{Keterampilan Kepemimpinan}

1. Definisi

Keterampilan kepemimpinan merupakan kemampuan individu dalam proses mempengaruhi kegiatan individu atau kelompok untuk mencapai tujuan bersama. Keterampilan dalam memimpin orang lain saling menyesuaikan antara kepribadian pemimpin dan yang dipimpin (Putong, 2015).

2. Ciri-ciri individu yang memiliki keterampilan kepemimpinan (Trought, 2017) 
a. Inovatif dan kreatif untuk menghadapi tantangan dalam memimpin.

b. Mampu mempengaruhi kegiatan individu atau kelompok untuk mencapai tujuan bersama.

3. Urgensi keterampilan kepemimpinan dalam dunia karier (Trought, 2017)

a. Mendorong tercapainya kesuksesan di seluruh bidang pekerjaan.

b. Kepemimpinan digunakan untuk mencapai tujuan bersama.

c. Kepemimpinan dapat menggerakan, memberdayakan, dan mengarahkan sumber daya secara efektif dan efisien kearah pencapaian tujuan.

\section{Keberanian Berusaha}

1. Definisi $\begin{array}{cc}\text { Keberanian } & \text { berusaha } \\ \text { merupakan kemampuan } & \text { individu }\end{array}$ mendorong afeksi untuk mengambil resiko dan siap dalam menghadapi tantangan (Trought, 2017).

2. Ciri-ciri individu yang memiliki keberanian berusaha (Trought, 2017)

a. Kreatif dan inovatif.

b. Mampu mengembangkan keterampilan inisiatif.

c. Mampu memanfaatkan peluang.

d. Mampu mengembangkan produk dan proses baru dari dalam organisasi.

3. Urgensi keberanian berusaha dalam dunia karier (Trought, 2017)

a. Keberanian dalam berusaha mendorong individu agar analitis dan kreatif dalam mengambil keputusan.

b. Dewasa ini dunia karier membutuhkan individu yang memiliki kemampuan untuk memahami dan menafsirkan proses saat ini, cara keterkaitannya, dan memberi kesempatan untuk mengidentifikasi area untuk perbaikan.

c. Keberanian memungkinkan

berusaha memanfaatkan individu peluang,

\section{Kecerdasan Emosional}

1. Definisi

$$
\text { Kecerdasan emosional }
$$
merupakan kemampuan individu memanajemen diri, memanajemen hubungan, dan memanajemen lingkungan dari sisi emosional secara efektif. Kemampuan mengelola kecerdasan emosional menuntut individu agar mandiri, realitis, dan fleksibel (Trought, 2017).

2. Ciri-ciri individu yang memiliki kecerdasan emosional (Trought, 2017)

a. Mampu bersikap simpati dan empati.

b. Mampu mengendalikan diri.

c. Mampu menginspirasi, mempengaruhi, mengembangkan orang lain, menantang status quo, dan mengelola konflik.

d. Mampu mengenali bagaimana perasaan akan mempengaruhi kinerja pekerjaan.

e. Mampu mengelola dan merespon tantangan dengan tepat.

f. Mampu membuat keputusan berdasarkan fakta dan data yang berkaitan.

g. Mampu merasakan emosi.

h. Mampu mengakses dan membangkitkan emosi.

i. Memahami emosi dan pengetahuan emosional.

3. Urgensi kecerdasan emosional dalam dunia karier (Trought, 2017)

a. Individu akan terus menghadapi tantangan, menuntut dan mengubah pandangan, sehingga individu perlu mengelola dan meresponnya dengan tepat. 
b. Organisasi semakin menyadari bahwa kecerdasan emosional pekerja mereka memegang peranan penting dalam menentukan respons individu terhadap suatu situasi atau terhadap orang lain.

\section{Bimbingan Klasikal}

Layanan bimbingan dan konseling di dalam kelas (bimbingan klasikal) merupakan layanan yang dilaksanakan dalam seting kelas, diberikan kepada semua peserta didik, dalam bentuk tatap muka terjadwal dan rutin setiap kelas per minggu. Volume kegiatan tatap muka secara klasikal (bimbingan klasikal) adalah 2 (dua) jam per kelas per minggu dan dilaksanakan secara terjadwal di kelas. Materi layanan bimbingan klasikal meliputi empat bidang layanan yang diberikan secara proporsioal sesuai kebutuhan peserta didik/konseli yang meliputi aspek perkembangan pribadi, sosial, belajar dan karier dalam kerangka pencapaian perkembangan optimal peserta didik dan tujuan pendidikan nasional. Materi layanan bimbingan klasikal disusun dalam bentuk Rencana Pelaksanaan Layanan Bimbingan Klasikal (RPLBK). Bimbingan klasikal diberikan secara runtut dan terjadwal di kelas dan dilakukan oleh konselor yaitu pendidik profesional yang minimal berkualifikasi akademik Sarjana Pendidikan (S1) dalam bidang Bimbingan dan Konseling dan lulus pendidikan profesi guru bimbingan dan konseling/konselor, atau guru Bimbingan dan konseling yang berkualifikasi minimal Sarjana Pendidikan (S-1) dalam bidang bimbingan dan konseling dan bersertifikat pendidik.

Brewer menggunakan bimbingan klasikal sebagai sarana mempersiapkan peserta didik untuk mengatur berbagai bidang kehidupannya supaya bermakna dan memberikan kepuasan, seperti bidang kesehatan, bidang pekerjaan, bidang kehidupan keluarga, bidang kehidupan bermasyarakat, dan bidang rekreasi (Winkel, 1991). Secara teknis operasional, topik-topik bimbingan dalam bimbingan klasikal ditentukan berdasarkan pada rumusan standar kompetensi kemandirian peserta didik (SKKPD), pada setiap aspek perkembangan, sesuai dengan jenjang pendidikan yang juga dikembangkan berdasarkan tugas perkembangan yang harus dicapai oleh peserta didik. Berdasarkan kompetensi kemandirian tersebut yang dirumuskan dalam tataran pengenalan, akomodasi dan tindakan, kemudian dirumuskan topik-topik materi bimbingan yang relevan dengan kebutuhan (dari hasil asesmen kebutuhan), untuk mencapai kompetensi yang dimaksud (Ramli et al., 2017).

\section{METODOLOGI}

Penelitian ini ditujukan kepada peserta didik kelas XII IPS SMA Negeri 14 Jakarta. Jumlah populasi sejumlah 72 orang peserta didik. Teknik sampling yang digunakan adalah sampling jenuh dengan jumlah sampel 72 orang. Metode penelitian yang digunakan peneliti adalah metode research and development (R\&D) dengan menggunakan model ADDIE (Analyze, Design, Development, Implementation, dan Evaluation). Adapun tahapan pengembangan yang dilakukan peneliti yaitu tahap analisis, desain, dan pengembangan. Teknik pengumpulan data yang digunakan adalah wawancara, observasi, studi dokumentasi, kuesioner/angket, dan triangulasi/gabungan. Penilaian produk dilakukan oleh validator yang terdiri dari ahli media, ahli materi, dan peserta didik.

\section{HASIL PENELITIAN}

Penelitian ini menghasilkan produk audiovisual berupa video dokumenter mengenai role model yang memiliki employability skills. Tahapan penelitian yang dilakukan adalah analisis, desain, dan pengembangan. Berikut ini adalah hasil penelitian yang didapatkan:

Preliminary study dibagi menjadi tiga bagian, yaitu pengetahuan mengenai employability skills, kebutuhan pada video dokumenter, dan efektivitas role model. Berdasarkan hasil preliminary study pengetahuan mengenai employability skills 
didapati bahwa: (1) 63 orang peserta didik $(88 \%)$ memahami ciri-ciri manajemen diri; (2) 55 orang $(76 \%)$ memahami definisi keterampilan kepemimpinan; (3) 46 orang (64\%) memahami definisi keterampilan menyelesaikan masalah; (4) 52 orang $(72 \%)$ memahami definisi kecerdasan emosional; (5) 58 orang $(81 \%)$ memahami definisi keterampilan kerjasama; (6) 60 orang $(83 \%)$ memahami definisi keterampilan matematik; (7) 38 orang (53\%) memahami ciri-ciri keterampilan komunikasi; (8) 49 orang $(68 \%)$ memahami urgensi keterampilan matematik di dalam dunia karier; (9) 39 orang (54\%) memahami definisi manajemen diri; (10) 62 orang (86\%) memahami ciri-ciri keterampilan kerjasama; (11) 45 orang (63\%) memahami definisi kesadaran pada karier; (12) 37 orang (51\%) memahami definisi kecerdasan emosional; (13) 70 orang (97\%) memahami ciri-ciri keterampilan kepemimpinan; (14) 56 orang $(78 \%)$ memahami urgensi keterampilan komunikasi di dalam dunia karier; (15) 51 orang (71\%) memahami urgensi manajemen diri; (16) 56 orang (78\%) memahami urgensi keterampilan kerjasama di dalam dunia karier; (17) 68 orang (94\%) memahami definisi keterampilan mengelola teknologi dan informasi; (18) 49 orang (68\%) memahami ciri-ciri keberanian berusaha; (19) 39 orang (54\%) memahami ciri-ciri keterampilan matematik; (20) 47 orang (65\%) memahami definisi keterampilan komunikasi; dan (21) 42 orang $(58 \%)$ memahami ciri-ciri kesadaran pada karier. Berdasarkan data tersebut sebagian besar peserta didik sudah memahami beberapa keterampilan dalam employability skills.

Namun, hasil dari preliminary study juga menunjukan bahwa peserta didik belum memahami beberapa keterampilan dalam employability skills. Hal tersebut dapat dilihat pada hasil preliminary study bahwa terdapat: (1) 31 orang (43\%) memahami urgensi mengelola teknologi dan informasi di dalam dunia karier; (2) 5 orang (7\%) memahami urgensi keterampilan menyelesaikan masalah di dalam dunia karier; (3) 27 orang (38\%) memahami urgensi kecerdasan emosional di dalam dunia karier; (4) Tidak seorang pun memahami urgensi keterampilan kepemimpinan; (5) 27 orang (38\%) memahami ciri-ciri keterampilan menyelesaikan masalah; (6) 28 orang (39\%) memahami urgensi keberanian berusaha di dalam dunia karier; (7) 14 orang (19\%) memahami ciri-ciri keterampilan mengelola teknologi dan informasi; (8) 15 orang (21\%) memahami definisi keberanian berusaha; dan (9) 14 orang (19\%) memahami urgensi kesadaran pada karier di dalam dunia karier. Berdasarkan data tersebut, maka dapat dilihat bahwa peserta didik belum memiliki pengetahuan mengenai keterampilan kerja secara keseluruhan.

Berdasarkan hasil preliminary study kebutuhan pada video dokumenter didapati bahwa: (1) 55 orang $(76 \%)$ peserta didik merasa tertarik pada video dokumenter; (2) 57 orang $(79 \%)$ merasa tertarik menggunakan video dokumenter sebagai media pembelajaran; (3) 67 orang (93\%) mampu memahami pesan yang terkandung dalam video dokumenter yang pernah ditonton; (4) 57 orang (79\%) merasa termotivasi oleh pesan yang terkandung tersebut; dan (5) 39 orang (54\%) mengakui adanya video dokumenter yang dianggap menarik. Namun, hanya 6 orang $(8 \%)$ yang menjawab guru BK pernah menggunakan video dokumenter untuk membahas informasi karier. Data tersebut menunjukan bahwa video dokumenter merupakan media pembelajaran yang dibutuhkan oleh peserta didik kelas XII IPS SMA Negeri 14 Jakarta.

Preliminary study mengenai efektivitas role model ditentukan berdasarkan tiga bagian, yaitu jenis kelamin, kelompok usia, dan bidang profesi atau pekerjaan. Berdasarkan jenis kelamin, sebanyak 38 orang $(53 \%)$ memiliki minat pada role model laki-laki. Berdasarkan kelompok usia, 45 orang $(63 \%)$ memilih kelompok usia 25-34 tahun. Berdasarkan bidang profesi atau pekerjaan, 38 orang (53\%) memilih role model di bidang pendidikan. Maka itu, narasumber yang dipilih adalah 
role model dengan jenis kelamin laki-laki di kelompok usia 24-35 tahun yang memiliki profesi atau pekerjaan di bidang pendidikan.

Hasil penelitian tersebut menghasilkan Video Dokumenter Role Model yang Memiliki Employability skills, yaitu video dokumenter berdurasi 14 menit dan 22 detik tentang seorang lelaki berusia 29 tahun yang bekerja sebagai guru olahraga di sebuah sekolah di Jakarta dan memiliki employability skills. Employability skills yang dimaksud akan menjelaskan tentang definisi, ciri-ciri individu yang memiliki keterampilan tersebut, dan urgensi keterampilan tersebut dalam dunia karier pada keterampilan manajemen diri, komunikasi, kepemimpinan, kecerdasan emosional, kerjasama, keberanian berusaha, kesadaran pada karier, keterampilan menyelesaikan masalah, keterampilan mengelola teknologi dan informasi, dan keterampilan matematik.

Berdasarkan penelitian pengembangan produk yang telah dilakukan oleh peneliti, hasil evaluasi formatif oleh ahli media, ahli materi, dan uji coba peserta didik memperoleh hasil dengan kategori layak. Hal ini dapat dilihat dari persentase yang diperoleh. Uji coba ahli media memperoleh hasil $81,25 \%$ dan termasuk pada kategori layak. Uji coba ahli materi memperoleh hasil $77,56 \%$ dan termasuk pada kategori layak. Uji coba peserta didik yang dilakukan pada 72 orang memperoleh hasil $71,25 \%$ dan termasuk pada kategori layak.

\section{KESIMPULAN}

Pengujian yang dilakukan oleh ahli media dan ahli materi mendapati data bahwa video dokumenter layak digunakan. Berdasarkan hasil pengolahan data pilot test didapati hampir seluruh peserta didik memahami employability skills.

Penelitian yang dilakukan peneliti hanya sampai pada tahap pengembangan. Penelitian tidak dilakukan hingga tahap implementasi dan evaluasi karena tujuan dari penelitian ini hanya sebatas mengembangkan dan menghasilkan suatu media pembelajaran yang valid untuk diimplementasikan.

Video dokumenter ini perlu diperbaiki sesuai dengan hasil pengujian yang telah dilakukan. Secara keseluruhan video dokumenter layak digunakan sebagai media pembelajaran mengenai employability skills untuk peserta didik kelas XII IPS SMA Negeri 14 Jakarta dengan syarat perbaikan.

Penelitian ini dapat dikembangkan lebih lanjut oleh peneliti selanjutnya. Peneliti selanjutnya dapat melakukan penelitian pada tahap berikutnya, yaitu tahap implementasi dan tahap evaluasi. Pengembangan penelitian ini dapat memberikan gambaran efektivitas media yang telah dikembangkan peneliti serta memperbaiki yang menjadi kekurangan pada video dokumenter ini. Namun, sebelum itu peneliti perlu menggunakan instrumen pengetahuan peserta didik mengenai employability skills yang valid. Peneliti juga perlu menggunakan instrumen yang valid untuk menentukan role model dan penguji ahli yang memumpuni di bidangnya.

\section{DAFTAR PUSTAKA}

Aitken, I. (2013). Film and reform: John Grierson and the documentary film movement. London: Routledge.

Baron, R. A., \& Branscombe, N. R. (2014). Groups and Individuals: The Consequences of Belonging. In R. A. Baron \& N. R. Branscombe (Eds.), Social Psychology (13th ed., pp. 419458). Harlow, UK: Pearson Education Limited.

Bawantara, A. (2008). Panduan Membuat Video Keluarga. Depok: Kawan Pustaka.

Desrianti, D. I., Rahardja, U., \& Mulyani, R. (2012). Audio Visual As One Of The Teaching Resources On Ilearning. Journal CCIT, 5(2), 135-136.

Erikson, E. (2004). Erikson and Personal Identity: A Biographical Profile.

Erikson, E. H. (1968). Identity: Youth and crisis. New York: WW Norton \& Company. 
Fachruddin, A. (2015). Cara kreatif memproduksi program televisi. Yogyakarta: Andi Offset.

Fachruddin, A. (2017). Dasar-Dasar Produksi Televisi: Produksi Berita, Feature, Laporan Investigasi, Dokumenter Dan Teknik Editing. Kencana.

Gazier, B. (2001). The Complexity of Policy Notion. In P. Weiner, P. Weinert, M. Baukens, P. Bollerot, M. Pineschi, \& U. Walwei (Eds.), Employability: From Theory to Practice. London: Transaction Publisher.

Gracinia, J., \& Mulyani, Y. (2013). Kemampuan Fisik, Seni, dan Manajemen Diri. Elex Media Komputindo.

Monica, M. A., \& Susanti, D. (2016). Efektivitas bimbingan klasikal menggunakan media audio-visual untuk mengembangkan interaksi sosial peserta didik kelas VIII semester ganjil di SMPN 26 Bandar Lampung tahun pelajaran 2016/2017. Jurnal Bimbingan Dan Konseling, 3(2), 331-346.

National Union of Students. (2011). Working towards your future. Making the most of your time in Higher Education. CBI.

Prijosaksono, A. (2001). Self mangement series. Jakarta: Gramedia.

Puspitasari, N. A. (2014). Penggunaan Film Dokumenter Sebagai Media Dalam Meningkatkan Prestasi Belajar Siswa Pada Mata Pelajaran PPKN Di Kelas X-Mm SMK Muhammadiyah 5 Kepanjen. Jurnal Pendidikan Kewarganegaraan Universitas Negeri Malang, 1(1), 1-12.

Putong, I. (2015). Kepemimpinan: Kajian Teoritis dan Praktis. Jakarta: Buku\&Artikel Karya Iskandar Putong.

Ramli, M., Hidayah, N., Zen, E. F., Flurentin, E., Lasan, B. B., \& Hambali, I. (2017). Bimbingan Klasikal dan Kelompok. Jakarta:
Kementrian Pendidikan dan Kebudayaan Direktorat Jendral Guru dan Tenaga Kependidikan.

Rikarno, R. (2015). Film Dokumenter Sebagai Sumber Belajar Siswa. Ekspresi Seni: Jurnal Ilmu Pengetahuan Dan Karya Seni, 17(1), 129-149.

Santoso, E. J. (2013). Bikin video dengan Kamera DSLR. Jakarta: MediaKita.

Sharf, R. S. (1992). Applying career development theory to counseling. Applying Career Development Theory to Counseling. California: Woodswoth.

Suhartini, Y. (2015). Pengaruh Pengetahuan, Keterampilan dan Kemampuan Karyawan terhadap Kinerja Karyawan (Studi pada Industri Kerajinan Kulit di Manding, Bantul, Yogyakarta). Akmenika: Jurnal Akuntansi Dan Manajemen, 12(2).

Suneela, E. R. (2014). Soft skills are employability skills; with special reference to communication skills. Journal of Humanities and Social Sciences, 19(8), 59-61.

Syafitri, M., \& Heriyanto, M. (2013). Kesadaran, Lingkungan, dan Budaya Kerja. Jurnal Administrasi Pembangunan, 1(2), 129-134.

The Conference Board of Canada. (2000). Employability Skills. Retrieved from https://www.conferenceboard.ca/docs/ default-source/educpublic/esp2000.pdf?sfvrsn=0

Trought, F. (2017). Brilliant employability skills: How to stand out from the crowd in the graduate job market (2nd ed.). London, United Kingdom: Pearson.

Winkel. (1991). Psikologi Pengajaran. Yogyakarta: Gramedia Pustaka.

Wiryanto. (2004). Pengantar Ilmu Komunikasi. Jakarta: Grasindo. 